\title{
Başbaki Kulluğu'ndan Vergi Denetim Kurulu Başkanlığı'na Vergi Denetim Müesseseleri, Günümüz Sorunları ve Çözüm Önerileri*
}

\author{
Abdullah MARUFOĞLU** Ramazan GÖKBUNAR****
}

$\ddot{O} Z$

Vergi matrahlarının tespit edilmesi sürecinde olağan (beyan usulü) ve olağanüstü (ikmalen, re'sen ve idarece tarhiyat usulü) şeklinde iki usul yer almaktadır. Türk vergi sisteminin temeli de modern vergi sistemlerindeki gibi beyan esasina dayanmaktadır. Beyan esasi sistemine dayall vergi sistemlerinde vergi denetimi modern vergi düzeninin sağlanabilmesi bakımindan oldukça önem arz etmektedir.

Kişiler pek çok sebep dolayısıyla vergiye tabi matrahlarını en aza indirme gayreti göstererek, kanunen kabul edilen sınırların dışına çıkabilmektedirler. Vergi mükelleflerinin kanun dışı yollara başvurması, vergi kayıp ve kaçaklarının miktarının artmasına neden olarak devletin tahsil etmesi gereken kamu gelirlerinin azalmasina neden olmaktadır.

Devlet, vergi denetim araçlart olan yoklama, vergi incelemesi, arama ve bilgi toplama sayesinde, söz konusu kanunların çizdiği çerçevenin dışına çıkmış olan mükellef davranışlarını tespit ederek, gerekli cezai yaptırımlar uygulanmasını sağlar.

Bu çalışmada, vergi denetiminin tarihçesinin yanı sıra 2011 yılında 646 sayılı kanun ile vergi denetim kurumlarını tek çatı altında toplamış olan Vergi Denetim Kurulu Başkanlığı incelenmiştir.

Anahtar Kelimeler: Vergi, Denetim, Vergi Denetimi, Maliye Müfettişliği, Vergi Denetim Kurulu

JEL Sinıflandırması: H1, H2, H50, K34

\section{Tax Inspection Institutions from Basbaki Kullugu to Turkish Tax Inspection Board, Current Problems and Solution Suggestions}

\begin{abstract}
There are two methods: ordinary (declarative method) and extraordinary (replenishment, re-inspection and administrative tax procedure) in the process of determining the tax bases. The basis of the Turkish tax system is based on the principle of declaration as in modern tax systems. Tax audit is crucial to ensure modern tax regulation in tax systems based on principle of declaration.

People are able to go out of legal boundaries by struggling to reduce the minimum level of their tax base because of so many reasons. If the taxpayers use illegal methods, it causes to a decrease

\footnotetext{
* Bu makale, Manisa Celal Bayar Üniversitesi Sosyal Bilimler Enstitüsü, Maliye Anabilim Dalı'nda, Prof.Dr. Ramazan Gökbunar'ın tez danışmanlığında hazırlanmış olan "Türkiye'de Vergi Denetiminin Kurumsal Gelişimi: Vergi Denetim Kurulu Başkanlığı" (21.08.2017) başlıklı yüksek lisans tezinden üretilmiştir.

** Arş. Gör., Manisa Celal Bayar Üniversitesi, Maliye Bölümü, marufogluabdullah@gmail.com, ORCID Bilgisi: 0000-0001-6385-6488

**** Prof. Dr., Manisa Celal Bayar Üniversitesi, Maliye Bölümü, ramazan.gokbunar@cbu.edu.tr, ORCiD Bilgisi: 0000-0003-2084-7332
} 
in the public revenues that the state has to collect because it causes an increase in the amount of tax losses and evasion, There are different ways that tax auditing tools are used such as surveys, tax audit, search and prospecting, the taxpayers' behaviors which are out of the frame drawn by the state with related laws are detected and the necessary penal sanctions are applied.

In this study, tax audit, the history of tax audit and finally the presidency of tax inspection board passed tax audit institutions under a single roof, by being made actual through the law No. 646 statutory decree On July 10.07.2011 has been examined. As a result of the researches carried out, the problems encountered in tax auditing were identified and solutions were offered to the points where they were insufficient.

Key Words: Tax, Audit, Tax Audit, Finance Inspectorate, Tax Inspectorate

JEL Classification: $\mathrm{H1}, \mathrm{H} 2, \mathrm{H} 50, \mathrm{~K} 34$

\section{GíRIŞ}

Devletlerin egemenlik hakkından kaynaklanan, cebri usulde ve doğrudan bir karşılığı olmayacak biçimde, yapmak zorunda olduğu bir takım kamusal harcamaların finansmanı için vatandaşlarından maddi güçleri oranında tahsil ettiği vergiler, bütçe içinde en önemli gelir kalemini oluşturmaktadır.

Ödenecek vergilerde, mükelleflerin rızalarının aranmaması, ödenen vergilerin mükellefler açısından doğrudan bir karşılığg olmaması, kamunun katı sinırlamalar getirmesi ve vergi yükününün ağır olması gibi nedenlerden dolayı mükellefler vergi ödevlerini yerine getirme noktasında bir direnç gösterebilmektedirler. Bu noktada vergi ödevini yerine getirmekte direnç gösteren mükelleflerin denetimi oldukça önem arz etmektedir.

Geçmişten günümüze vergi denetimi görevini üstlenen birçok kurum olmuştur. Osmanlı Devleti zamanında Başbaki Kulları aracılığıyla vergi denetimleri gerçekleştirmiştir.

Tanzimat'ın ilanından kısa bir süre önce kaldırılan Başbaki Kulluğu müessesi yerini, 25 Temmuz 1879 tarihinde yayımlanan "Teftiş Muamelatı Maliye Nizamnamesi" ve "Heyet-i Teftişiye-i Maliye" ile Maliye Teftiş Kurulu almıştır.

Türkiye Cumhuriyeti’nin mali yapısının kuruluşu ve gelişim sürecinde, modern anlamda vergi denetimi Maliye Teftiş Kurulu ile başlamış ve çeşitli gereksinimler doğrultusunda Hesap Uzmanları, Gelirler Kontrolörleri ve Vergi Denetmenleri de vergi denetimine dâhil olmuştur. 10.07.2011 tarihinde Resmi Gazete'de yayımlanarak yürürlüğe giren 646 sayılı KHK ile vergi denetimlerinde çok başlılığın oluşturduğu sorunları engellemek amacıyla Vergi Denetim Kurulu (VDK) kurularak, vergi denetimi günümüzdeki halini almıştır.

$\mathrm{Bu}$ çalışmayla; vergi denetiminin gelişim süreci, Osmanlı Devleti'nden günümüze dek kurulmuş olan vergi denetim kurumlarının kuruluş amaçları ve üstlendikleri görevlere dair açıklamalar ile Vergi Denetim Kurulu'nun faaliyetleri incelenmiş ve vergi denetimine ilişkin kurumsal sorunlara çözüm önerileri getirilmeye çalışılmıştır.

\section{GEÇMIŞTEN GÜNÜMÜZE BAŞLICA VERGİ DENETIM KURUMLARI}

Osmanlı mali sisteminin denetlenmesinin tam olarak hangi tarihte ortaya çıktığı bilinmiyor olmasına rağmen, Selçuklu modeli etkisi görülmektedir.

Osmanlı Devleti’nde mali denetim mekanizmasının oluşması 1879 yılında 
Maliye Teftiş Heyeti ile başlamış olsa da ilk mali denetim teşkilatı olarak Başbaki Kulluğu kabul edilmektedir.

Başbaki Kulluğu ile başlayıp Maliye Teftiş Heyeti’nin ortaya çıktığı zamana kadar geçen sürede, Maliye Nezareti'nin kurulması ile beraber, Tanzimat Dönemi'ne ait mali konulardaki sorunları aşmak, devlete ait gelir kaynaklarının ve giderlerinin denetlenmesi amacıyla birçok meclis ve komisyon oluşturulmuştur (Tabakoğlu ve Taşdirek, 2015: 91).

\section{A. Başbaki Kulluğu}

Başbaki Kulluğu, 16. yüzyılın başlarından Maliye Nezareti'nin kuruluşunun gerçekleştiği zamana kadar Osmanlı Devleti’nin mali açıdan denetlenmesi görevini yürütmüştür. Bu kurum üstlenmiş olduğu mali denetim görevini 250 yılı aşkın süreyle devam ettirerek 19. yüzyılın ilk devreleriyle beraber daha modern kuruluşlara devretmiştir. Maliye Nezareti'nin 1838 senesinde kuruluşu ile beraber mali denetim, oldukça kısa bir zaman zarfinda maliye müfettişleri aracılığıyla devam ettirilmiştir. Daha sonrasında vergi gelirlerinin tahsil edilememesi, devletin gelir ve giderlerinin ortak bir havuzda denetlenememesi gibi sorunlara çözüm üretilebilmesi adına çeşitli meclis ve komisyonların oluşturulması yoluna gidilmiştir (Çelebiler ve Güvemli, 2013; 45 46; Tabakoğlu ve Taşdirek, 2015: 92). Aşağıdaki Şekil 1'de genel olarak Osmanlı mali denetim sisteminin kurumsal yapısının gelişim süreci yer almaktadır.

Şekil 1: Osmanlı Mali Denetim Sisteminin Kurumsal Yapısının Gelişim Süreci

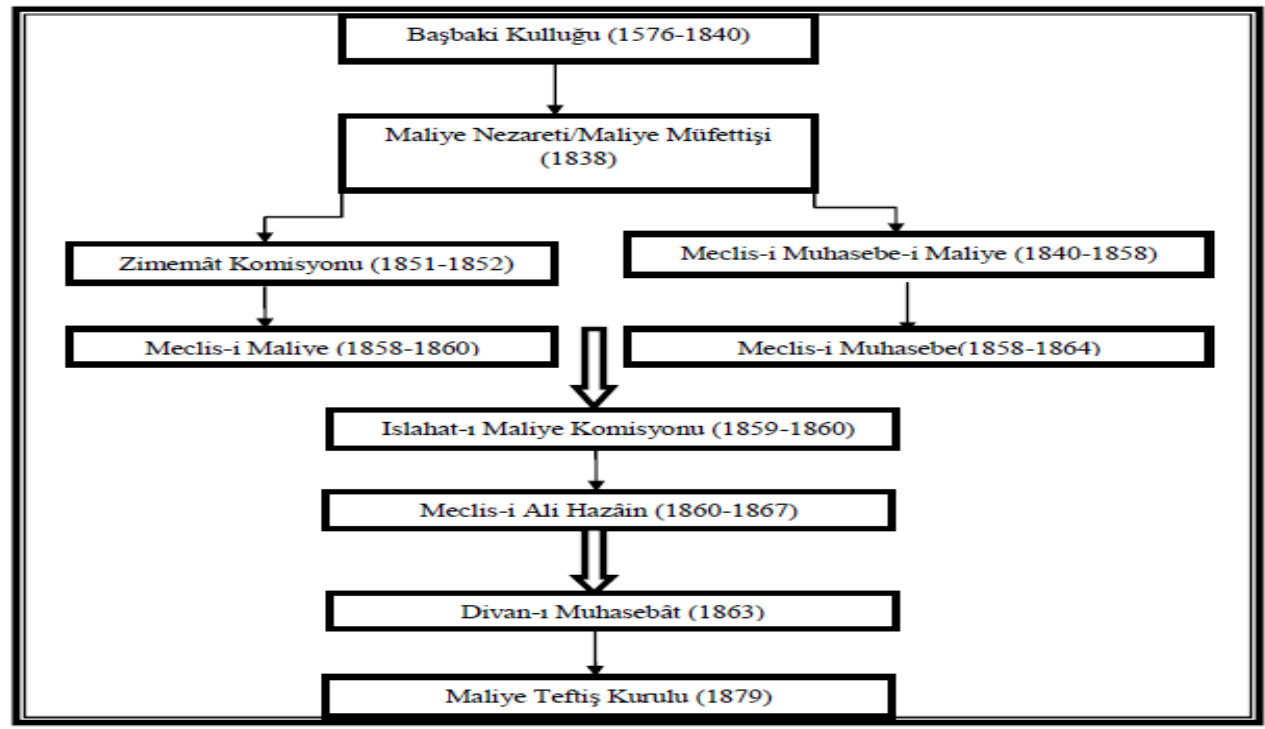

Kaynak: Tabakoğlu, A. \& Taşdirek, O. Ç. (2015). Osmanlıda Mali Denetimin Kurumsal Gelişimi-Maliye Teftiş Heyetinin Kuruluşu. Yönetim ve Ekonomi Araştırmaları, S.2.

Osmanlı Devleti'nde Başbaki Kulluğu, muhasebe teşkilatı bünyesinde muhasebe kayıtlarını tutan devlet görevlisiydi (Bkz. Ek 1). Zaman içinde muhasebe bölümünden ayrılarak farklı bir alan şekline dönüşmüş ve daha etkin bir duruma gelmiştir. Bu alan nezdinde görevli olarak belirlenen kişi, Başbâkî kulu şeklinde isimlendirilmiştir. Başbâkî ifadesindeki baş "yüksek yetkiyi" bâkî ise "tahsil 
olunmayan, bakiye" anlamlarını ifade etmektedir. Kul ise devlet adına görevlendirilmiş kişi, memur anlamına gelmektedir. Başbâkî kulu, devletin gelirlerini yöneten gelir idaresinin kalan bakiyelerini tahsil etmekle görevlendirilmiş yöneticidir (Kesik ve Oğuz, 2013: 1-3).

Denetim alanında Osmanlı Devleti'nin Tanzimat Fermanı öncesi dönemi incelendiğinde en etkili teşkilat olarak karşımıza Defterdarlık müessesi altında görevli olan Başbâkî Kulluğu teşkilatı çıkmaktadır ${ }^{1}$. Defterdarlık makamı, Divan-1 Hümayun'dan sonra Osmanlı yönetiminde en önemli kurum olarak kabul edilirdi. Defterdarlığın kuruluşu bilinmediği gibi Başbâkî Kulluğu'nun da tam olarak hangi tarihte kurulduğu hakkında kesin bir bilgi mevcut değildir ${ }^{2}$ (Günalan, 2010: 17; Pur, 2015: 25). Fakat defterdarlık altında böyle bir görevi icra eden görevli bulunması ihtimaller dâhilinde olsa bile bunun bir daire şeklinde oluşumu 1650 y1lından sonra vuku bulmuştur³.

Çeşitli vesika ve kaynaklarda "ser-gulamı baki" olarak da adlandırılan başbâkî kulu kamuya ait gelirlerin tahsilatında etkin görev üstlenen bir memurdu. Başbâkî Kuluna bağlı olarak çalışan uzmanlar da memur olarak tanımlanır ve Baki Kulları olarak adlandırılırdı. Doğrudan defterdarlığa bağlı olan 5 daireden biri olan Başbâkî Kulluğu'nun emri altında çalışan kişi sayısı 60 dolaylarındaydı. Bu kişiler devlete borcunu ödemeyenleri, üzerlerinde kamuya ait mal bulundurmakta olanları tespit ederek gerekli tahsilatları gerçekleştirirlerdi. Başbâkî Kulluğu'nun himayesine çalışan baki kulları bazı zamanlarda diğer mali alanda çalışan devlet görevlilerinin iş yükünü azaltmaya çalışır, ayrıca yoklama ve teftiş amacıyla taşra vilayetlerinde de görevlendirilirlerdi. Devlete borcu bulunan kişiler Başbaki Kulu tarafından şahsi konağında gözaltına alınırdı. Bu konak soruşturmanın gerçekleştirildiği, devlete borçlu olan ya da şahsında kamuya ait olan bir mal bulunduran kişilerin bu sorumluluklarını tamamlayacağı süreye kadar kaldıkları bir hapishane görevi görmüştür (Emecen, 1992: 126; Öner, 2005: 198).

18. yüzyıl itibariyle Başbaki Kulluğu'nun öneminin giderek artması nedeniyle devletin önemli isimleri bu mevkiye gelebilme adına çok çaba sarf etmişlerdir. Başbaki Kulluğu düzeni, 16. yüzyılın ikinci devresinden 1838 senesine kadar etkili olmuştur.

Başbaki Kulluğu müessesi Tanzimat'ın ilanından kısa bir süre önce kaldırılarak Tanzimat'ın ilanıyla birlikte bu görev maliye müfettişleri aracılığıyla yerine getirilmiştir (Emecen, 1992: 127; Tabakoğlu ve Taşdirek, 2015: 98).

\section{B. Maliye Teftiş Kurulu Müessesi}

Osmanlı Devleti, bütçe açıkları ve bununla beraber ortaya çıkan dış

\footnotetext{
${ }^{1}$ Fatih, bir fermanında Başbaki Kullarından şöyle söz eder: "Ben ki karaların, havaların ve denizlerin sultanı, ben ki yedi düvele hükmeden, Bakı Kuluma sözüm geçmez." (Pulur Hasan, "Bakı Kulundan Maliye Müfettişine”, 17.05.2008, İstanbul, Milliyet Gazetesi).

${ }^{2}$ Defterdarlık müessesesi, İlhanlı Devleti'nden miras kalan bir müessesedir. İlhanlılar yönetimi altında bulunan vilayetler mali işlerin kaydının tutulması amacıyla defterler hazırlatmışlardır ve bu defterleri tutmakla görevli kişilere "defterdar" adını vermişleridir (Karatepe, Selma \& Çapar, Selim "Türkiye Cumhuriyeti Bakanlıklar Tarihi”, s. 504. TİAV, 2019, Ankara).

${ }^{3}$ Söz konusu döneme ait vesikaların bazılarında bakaya denetimleri ile görevlendirilmiş olan kişilerle karşılaşıldığ gibi 1576 tarihine ait başka bir vesikada baki çavuşluğu isimli defterdara bağlı olarak devletin gelirlerini toplamakla yükümlü görevlilerin de bulunduğu anlaşıllmaktadır (Emecen, 1992: 126).
} 
borçların oluşturduğu baskı nedeniyle, mali sistem üzerinde etkili ve kalıcı reformları hayata geçirme anlamında zorluklar yaşamıştır (Bölükbaşı, 2012: 9-13).

Osmanlı Devleti'nde en önemli gider kalemi askeri harcamalardan oluşmaktaydı. Tanzimatla beraber artış eğiliminde olan askeri giderlerin finansmanı, elde edilen başarısız savaş sonuçları nedeniyle karşılanamaz hale gelmiştir. Bunun yanı sıra iyi düzenlenmiş bir tahsilat kurumunun olmayışı sonucunda, giderek artan gelir gider farkları oluşmuş ve büyük bütçe açıklarına neden olmuştur. Dış borçların karşılanamaması sonucunda Avrupalı alacaklıların borçlarının ödenmesi amacıyla 20 Aralık 1881 tarihinde "Düyun-u Umumiye İdaresi" kurulmuştur. Osmanlı Devleti yaşadığı mali sorunları en aza indirmek ve mali yapı üzerinde daha etkin bir denetim yapısı kurabilmek amacıyla mali açıdan merkezileşme politikası uygulanmaya başlamıştır (Doğan, 2015: 31,32; Tabakoğlu ve Taşdirek, 2015: 101; Varcan, 2000: 174 ).

Çağdaş gereksinimleri karşılamaktan uzak bir yapıda olan Osmanlı maliyesinin teftiş mekanizmasının modernleşmesi ve ihtiyaçlara cevap verebilmesi adına devrin maliye nazırı tarafindan II. Abdulhamid'e sunulan ${ }^{4}$ ve 25 Temmuz 1879 tarihinde dayanağını "İrade-i Seniye" den alan "Teftiş Muamelatı Maliye Nizamnamesi" ve "Heyet-i Teftişiye-i Maliye" (Maliye Teftiş Kurulü) oluşturulması Maliye Teftiş Kurulu'nun kuruluş tarihi olarak kaynaklarda kendine yer edinmiştir ${ }^{6}$. Maliye Teftiş Kurulu ile birlikte Osmanlı mali düzeni denetim altına alınarak gelirler arttırılmaya çalışılmıştır.

Nizamnamede belirtilenlere göre Kurulun üstlenmiş olduğu sorumluluk, "Devletin sahip olduğu malların tahsili ve gider kalemleri üzerinde yetkilendirilmiş olan maliye müdürlerinin, kaza mal memurlarının ve sandık eminlerinin, rüsumatların ve defteri hakanilerin (tapu), ormanların ve maadinlerin, postaların ve telgrafların yanı sıra İstanbul'da görev yapan tüm resmi dairelerdeki maliye memurlarının hesapları üzerinde incelemeler yaparak Nezarete bilgi verilmesidir" (Öner, 2005: 377).

Devlet gelirlerinin ve giderlerinin denetime tabi olmasıla beraber mevcut olan bütçe açıklarının yabancı ülkelerden borçlanılarak kapatılması yerine tasarruf edilerek finansmanının sağlanması, bu sayede dış borçlar sebebiyle tehlikeye giren

\footnotetext{
${ }^{4}$ Zühdü Efendi tarafından hazırlanmış olan nizamname tasarı sadrazamın görüşüne sunulmuştur. Tasarıda "İstanbul ile beraber büyük olarak kabul edilen vilayetlerin resmi daireleri ve şubeleri hakkında mali işlemleri belirtilen hesapların herhangi bir denetime muhatap olmadığı, söz konusu kayıtlar düzenli görünüyor olsa dahi güvenilebilir olabilmesi için denetimin mutlaka gerekli olduğu ifade edilmiştir. Denetim gerçekleştirilmez ise istenilen mali açıdan istikrarın mümkün olamayacağı, tek başına muhasebe kayıtlarının güven oluşturmaya yetersiz kaldığı, vergi kayıp ve kaçaklarının tespit edilip ortaya çıkarılamayacağı arz edilmiştir. Oluşturulacak denetim mekanizmasının ciddi maliyeti olabileceği fakat sağlayacağı fayda yanında bu maliyetin kabul edilebilir olduğu belirtilmiştir. Aynı layihada ayrıca ağnam, aşar ve devletin her türlü malının muhasebeleştirilmesi hususunda gerekli düzen ve tertip olmaması sebebiyle acilen tetkik ve teftiş yapabilecek yetkilere sahip Maliye Teftiş Heyeti'nin kurulması, önerisinde bulunulmuştur. Tezkerede Heyet içinde ortaya çıkacak kurulun bütçesi, maliye müfettişlerinin maaşları, görevleri ve nerelerde görevlerini gerçekleştirecekleri hakkında açıklamalar yapılmıştır. Söz konusu tezkerede ayrıca Maliye müfettişlerinin gerçekleştirdiği teftişlerin sonuçlarını bir inceleme raporu aracılığıyla Maliye Nezaretine sunacakları" belirtilmiştir (T.C. Cumhurbaşkanlığı Devlet Arşivleri Başkanlığı, İrade Meclis-i Mahsus, No.2979, 3 Temmuz 1879 (13 Recep 1296); Teftiş-i Muamelat-1). ${ }^{5} 1879$ yılından 1950'li yılına kadar Maliye Teftiş Kurulu "Heyet-i Mümtaze" olarak da adlandırılmıştır.

${ }^{6}$ BOA, İ.MMS, No.2979, 25 Temmuz 1879 (5 Şaban 1296); Maliye Teftiş Kurulu'nun Kuruluşuna Dair
} 
mali bağımsızlığın kurtarılması amaçlanmıştır. Bu doğrultuda padişahın elini güçlendirecek ve mali kaynakların merkezileşmesini sağlayacak çeşitli kurumlara gereksinim duyulması sebebiyle, maliye komisyonları oluşturulmuştur (Bölükbaşı, 2005: 123).

Devletin varlığının kaçınılmaz bir sonucu olan "mali işlev" ve bu işlev sonucunda ortaya çıkan Maliye Teftiş Kurulu, "kamuda mali yönetiminin" 130 yıl boyunca en önemli unsurlarından biri olmuştur. Bilindiği üzere "mali yönetim" işlevi devletten ayrı olarak asla düşünülemez. Mali açıdan devlet adına denetleme noktasında en köklü kurumlardan biri durumunda olan Maliye Teftiş Kurulu oldukça geniş sorumluluklar ve yetkilere sahip olmuştur (Altınok, 2008: 4; Macunluoğlu, 2010: 114).

Maliye Müfettişleri kendine münhasır özel kişilerdi ${ }^{7}$. Maliye müfettişi olmak kadar kurum içinde terfi olmak da bir o kadar zordu. Çeşitli komisyonlar sonucunda özgeçmişi terfi almaya yeterli ise ancak bir Maliye müfettişi terfi alabilirdi (Heyet-i Teftişiye-i Maliye adıyla 1900 yılına ait örnek bir terfi talep yazısı için bakınız Ek:2).

Maliye Teftiş Kurulu'nda görevli müfettişlerin teftiş görevlerini yerine getirirken uymak zorunda oldukları hususlar hakkında 9 Eylül 1879 tarihinde yürürlüğe giren bir nizamname hazırlanmıştır. Hazırlanan bu nizamname Teftiş Heyeti'nin görev şeklini belirleyen ilk yasal metin olarak bilinmektedir. "Teftiş- $i$ Muamelat-ı Maliye Nizamnamesi" adıyla yürürlüğe giren bu nizamname on yedi madde şeklinde sıralanmış bir düzenlemedir.

Kuruluş aşamasında çok sayıda çalışana sahip olmasına rağmen Maliye Teftiş Kurulu, kuruluşunu takip eden 1880 yılının sonunda kadrosu daraltılmıştır. Maliye Müfettişleri'nin sayısı ve görevleri 1884 yılında daha da azaltılarak gerçekleştirdikleri teftiş görevleri encümen mensupları aracılığıyla yaptırılması yoluna gidilmiştir. İzleyen yıllarda, Teftiş Kurulu'nun yönetimi ilk olarak Divanı Muhasebata (günümüz anlamında Sayıştay'ına) devredilmiş, 1888 senesinden II. Meşrutiyet'in ilanına kadar Maliye Müfettişliği bir meslek halini alamamıştır.

Fransız mevzuatının etkisiyle hazırlanan 5 Temmuz 1909 tarihli Nizamname (Tüzük) ile Maliye Teftiş Kurulu yeni bir düzene erişmiştir. Maliye Müfettişleri, 1909 tarihli Nizamname ile beraber Devlet dairelerinin tamamını denetleme yetkisine sahip olmanın yanında gerekli görülen durumlarda memurları açığa alma yetkisi gibi geniş yetkilere de sahip olmuştur. Ayrıca söz konusu Nizamname ile beraber Maliye Müfettişliği mesleğine sınav ile girilmesi şartı getirilmiştir. 1909 ile 1918 yılları arasında Teftiş Kurulu Başkanlığı'nı yabancılar sürdürmüştür. $\mathrm{Bu}$ süre zarfinda Maliye Müfettişleri'ne teftiş ve tahkik gibi işlere müdahil olma hakkı verilmemiş olup yalnızca kendi görev sınırları dâhilinde fikirlerini beyan etmelerine izin verilmiştir.

\footnotetext{
${ }^{7}$ Kendisi de Maliye Müfettişliği mesleğinden gelen Cemal Süreyya bir kitabında Maliye Müfettişleri hakkında şu satırları kaleme almıştır. "Dikkat edilirse, çok çeşitli kişileriz. Her kuşaktan, her anlayıştan insan var aramızda. Ama bir Maliye Müfettişi tipi de var. Dışımızda olanlara ve hele benzerlerimize hiç benzemiyoruz. Bizi biz eden de işte o benzemezlikte. Başkalarına karşı benzemezliğimiz içinde biz birbirimize çok benziyoruz. Kendi aramızdaki tek tek benzemezlikler de çeşitlilik, zenginlik olarak ortaya çıkıyor.” (MMD, 1987: 54). 
Maliye Bakanlığ ${ }_{1}^{8}$ çatısı altında yer almış olan Maliye Teftiş Kurulu, Devlete ait mali nitelik taşıyan tüm işlemleri Maliye Bakanlığı'nın Teşkilat Kanunu 1şığı altında denetimlerini gerçekleştirmekle yükümlü tutulmuşlardır. Cumhuriyetin ilanı ile beraber zaman içinde kanunlar değişerek, vergi denetimi ve kambiyo denetimlerinin yanı sıra faaliyet gösteren bankaların tamamı üzerinde denetim gerçekleştirebilme yetkisine de sahip olan Maliye Müfettişleri, imtiyazlı hisseler şeklinde kurulmuş şirketler ve dernekler nezdinde denetim ve inceleme yapma görevlerini de üstlenmişlerdi (Altınok, 2008: 4; Çelebiler ve Güvemli, 2013: 86).

Maliye Müfettişliği müessesi 10.07.2011 tarih ve 646 sayılı KHK ile kurulda görev yapan tüm denetim elemanları, Vergi Denetim Kurulu'nda, "Vergi Müfettişi" adıyla ama aynı yetkilere sahip şekilde görevlerini icra etmeye devam etmektedirler.

\section{Hesap Uzmanları Kurulu}

Türk vergi tarihinde önemli bir yeri olan ve beyana dayalı modern vergilerin temelini oluşturan "1950-Büyük Vergi Reformu”nun hazırlık çalışmaları 1943 'te başlamıştı. Bu çalışmaların sonuçlarından biri olarak 29 Mayıs 1945 tarihli 4709 sayılı Kanun ile Hesap Uzmanları Kurulu oluşturulmuştur?.

Kurulun kuruluş tarihi 1950 yılında yürürlüğe giren kapsamlı reformların öncesine denk gelmiştir ${ }^{10}$. Bu kurum ile birlikte vergi denetimi görevi doğrudan Maliye Bakanlığı'na bağlı bulunan Hesap Uzmanları Kurulu'na bırakılmıştır. Reform ile birlikte muamele vergisi hesap mütehassıslığı ile kazanç vergisi hesap mütehassıslığı unvanları kaldırılmış yerine hesap uzmanı (veya hesap uzman muavini) unvanı getirilmiştir (HUD, 2020: 1).

Hesap Uzmanları Kurulu'nun kuruluş amacını belirten iki önemli dayanak vard1. Bu dayanaklardan birincisi, İstanbul, Ankara, İzmir' de oluşturulan Muamele Vergileri ve Kazanç Vergileri denetimini gerçekleştiren grupları tek bir kurum çatısı altına alarak iki başıı denetim sisteminden kurtulmaktı. İkinci dayanak ise, kamu denetimi yöntemlerinin uygulanması sürecindeki standartların tek bir noktadan geliştirilmesi hususunda var olan engellerin kaldırılması ve bu engellerin kaldırılması ile birlikte muhasebe odaklı modern bir kamu vergi denetim sisteminin hayata geçirilmesiydi (Güney, 2013: 254).

Hesap Uzmanları Kurulu, çağdaş vergi anlayışındaki ilerlemeler ile eş

\footnotetext{
${ }^{8} 9$ Temmuz 2018 tarihli ve 30473 sayılı Resmî Gazete'de yer alan 747 nolu KHK ile Maliye Bakanlığı'nın ismi değiştirilerek Hazine ve Maliye Bakanlığı olmuştur. Çalışmanın bundan sonraki kısmında da dönem adıyla (Maliye Bakanlığı) kullanılması uygun görülmüştür.

${ }^{9} 4709$ sayılı Kanunun gerekçe kısmında şu ifadelere yer verilmiştir: “Maliye Vekaleti'ne bağll olarak merkezde bir Hesap Mütehasslsları Heyeti teşkiline dair olan merbut kanun projesi, bazı varidat kanunlarının bahşettiği selahiyete müsteniden takriben on seneden beri istihdam edilen hesap mütehassisl ve muavinlerinin esasl bir teşkilata raptedilerek her bakımdan daha mazbut ve mümtaz bir hale getirilmelerindeki aşikar fayda ve zaruretten ve bu mevzuda Büyük Millet Meclisi ve encümenlerin de izhar edilen temennilerden ilham alınarak hazırlanılmıştır." (http://www.hud.org.tr/icerik/tarihce Erişim Tarihi:22.03.2020).

${ }^{10} 1950$ 'li yılların başında yürürlüğe giren kapsamlı reformlar ile birlikte modern Türk Vergi Sisteminin altyapısı oluşturulmuştur. 1950’lerin başlarında gerçekleştirilen reformla çağdaş Türk Vergi Sisteminin temelleri atılmıştır. Bu kapsamda Kazanç Vergisi Kanunu yerini Gelir Vergisi Kanunu, Kurumlar Vergisi Kanunu ve VUK'a; Tahsili Emval Kanunu da yerini 6183 sayılı Amme Alacaklarının Tahsili Usulü Hakkında Kanun'a bırakmıştır.
} 
zamanlı bir şekilde gelişimini devam ettirmiştir. Hesap uzmanlar ${ }^{11}$ hazırlanan vergi düzenlemeleri ile görevli kalmayıp bunun yanı sıra yeni yürürlüğe girmiş veya girecek olan kanunlar hakkında mükelleflerin ve diğer ortakları bilgilendirilmesi, getirilecek yeni reformların adaptasyonu süresince Maliye Bakanlığı çalışanlarının eğitilmesi gibi görevlere de sahipti.

Hazırlanan maliye politikalarında en önemli araç olan vergiler noktasında uzmanlaşan, Hesap Uzmanları Kurulu, XX. yüzyılın ilk yarısının sonları ile birlikte vergi denetiminde modern toplumları yakalamayı sağlamış olan bir kurum olmuştur.

Hesap Uzmanları Kurulu da Maliye Müfettişliği Kurumu gibi 10.07.2011 tarih ve 646 sayılı KHK ile kapanarak Vergi Müfettişi adıyla kamuda görev yapmanın yanında, özel sektör ve uluslararası kuruluşlarda görevlerini farklı unvanlar altında yerine getirmektedirler.

\section{Ç. Gelirler Kontrolörleri Başkanlı̆ğı}

Gelirler Kontrolörlüğü, 29.05.1936 tarih ve 2996 sayılı Maliye Vekâleti Teşkilat ve Vazifeleri Hakkında Kanun ile "Varidat Kontrolörlüğü" adıyla kurulmuştur. Maliye Bakanlığı teşkilat yapısında gerçekleştirilen isim değişikliği sonucunda, 1946 yılında "Gelirler Kontrolörlüğü” adını almıștır.

Gelirler Kontrolörleri Başkanlığı 30 Kasım 1973 tarih ve 14728 sayılı Resmi Gazete yayımlanan yönetmelik çerçevesinde Gelirler Genel Müdürlügü merkez teşkilatı bünyesinde iç ve dış denetim birimi olarak görevlerini yerine getirmişlerdir ${ }^{12}$.

Gelirler Kontrolörleri; Türkiye genelinde vergi incelemeleri gerçekleştirmek, gelir idaresine ait merkez ve taşra yapılanmasına dair yürütülen faaliyetleri denetleme, görevli maliye memurları üzerinde soruşturmalar gerçekleştirme, 4208 Sayılı Kanunun verdiği yetkiye dayanarak kara para aklama işlemleri hakkında araştırmalar yapmak ve diğer çeşitli kanunlarda belirtilenler ile verilen kararlar neticesinde üzerine düşen denetim görevlerini yürütmekle görevli merkezi denetime ait bir denetim birimi olarak görev yapmıştır.

Gelirler Kontrolörleri, faaliyetlerini sürdürdüğü y1llarda Türkiye'nin giderek artan kamu harcamalarının karşılanması noktasında önem arz eden ve sürekli bir gelir kaynağı olan vergilerin mükelleflerce gerçeğe uygun bir şekilde ödenip ödenmediği ve bu hususta gerekli denetimlerin gerçekleştirilmesi esnasında hem gelir idaresinin verimli bir biçimde çalışmasını hem de mükellefler üzerinde vergi bilincinin oluşturulması görevlerini en iyi biçimde gerçekleştirmek için çaba sarf ederek ve ülkenin gelişimi için çağdaş denetimin tüm gereksinimlerini üstlenerek, en iyi ölçüde yerine getirmeye çalışmışlardır (Tezcan, 2003: 143).

VDK'nın kurulmasıyla birlikte Gelirler Kontrolörleri kaldırılmıştır.

\section{Vergi Denetmenleri}

Vergi Denetmenleri, Gelirler Kontrolörlüğü’nde olduğu gibi 29.05.1936

\footnotetext{
11 -o yil ki adıyla "hesap mütehassısı".

${ }^{12}$ Başkanlı̆̆ın merkez görev yeri Ankara olmasına karşın, İstanbul ve İzmir'de ayrı Grup Başkanlıkları da bulunuyordu. Ülkenin diğer şehirlerine turne dâhilinde görevlendirmeyle inceleme, teftiş ve tahkikat gerçekleştirmekteydiler.
} 
tarih ve 2996 sayılı "Maliye Vekâleti Teşkilat ve Vazifeleri Hakkında Kanun” ile o dönem ki adıyla "Varidat (Defterdarlık) Kontrol Memurları" kurulmuştur.

Söz konusu kanunun 44. maddesinde "Bu kanunda yazılı kontrol memurları, varidat kanunlarında yazılı tahakkuk ve tahsil müfettişlerine verilmiş olan hak ve salahiyetleri haizdirler." hükmü yer almış, yetkilerinin görev sınırları tahakkuk ve tahsil müfettişleri ile denkleştirilmiştir. "Varidat Kontrol Memuru" tanım1; 29 Mayıs 1946 tarihli ve 4910 say1lı Kanunla "Gelir Kontrol Memuru", 24 Mart 1950 tarihli ve 5655 sayılı Kanunla "Vergi Kontrol Memuru", 20 Ağustos 1993 tarihli ve 516 sayılı ve 19 Haziran 1994 tarihli ve 543 say1lı KHK'lar ile de "Vergi Denetmeni" şeklinde değişime uğramıştır (Mutlu, 1998: 3 \& Pekşen, 2019: 112).

Vergi Denetmenleri, Defterdarlık müessesi altında görev yapabilir iken aynı zamanda, 6 şehirde kurulmuş olan "Gelirler Bölge Müdürlükleri'nde" görevlerini yerine getirmişlerdir. Görevlerini ifa ederken 213 Sayılı VUK’a uygun şekilde denetimlerini ve vergi incelemelerini gerçekleştirmekte, üst merciler tarafından tahsis edilen denetim ve soruşturma görevlerini yerine getirmekle görevlendirilmişlerdir.

646 sayılı KHK yürürlüğe girene kadar GİB çatısı altında 29 ilde yer alan Vergi Dairesi Başkanlıklarına bağlı olarak, hem dış hem de iç denetim birimi olma özelliğine sahip olan Vergi Denetmenleri ve Vergi Denetmen Yardımcıları, vergi incelemesi gerçekleştirme görevine sahip olarak diş denetimi, teftiş ve soruşturma görevine sahip olarak iç denetim görevlerini yerine getirmekteydiler (Pekşen, 2019: 112).

646 sayılı KHK'nın yürürlüğe girmesi ile Vergi Denetmenliği unvanı kaldırılarak bu unvan altındaki denetim elemanları Vergi Müfettişi ve Vergi Müfettiş Yardımcısı kadrosuna atanmışlardır.

\section{VERGI DENETIM KURULU BAŞKANLIĞI KURULUŞU, MEVCUT DURUM, SORUNLAR ve ÇÖZÜM ÖNERILERİ}

\section{A. Vergi Denetim Kurulu Başkanlığ}

Ülkemizin vergi denetim sistemi 10.07.2011 tarihinden öncesine kadar, merkez ve taşra olarak iki farklı alanda ve 4 farklı kurum (Maliye Müfettişi, Hesap Uzman1, Gelirler Kontrolörü ve Vergi Denetmeni) aracılığıyla gerçekleştirilmiştir.

Merkez denetim birimi altında Bakana bağlı olarak Maliye Müfettişleri ile Hesap Uzmanları yer alırken, Gelirler Kontrolörleri ise Gelir İdaresi Başkanı'ndan almış oldukları yetki ile görevlerini yürütmüşlerdir. Öte yandan Vergi Denetmenleri de Vergi Dairesi Başkanlıkları'nın taşra teşkilatında görev yapmışlardır (Bkz. Şekil 2).

Aşağıdaki Şekil 2'de görüldüğü gibi vergi denetim kurumlarının dağınık bir yapıya sahip olması yalnızca verimli ve etkin bir çalışma süreci oluşmasına engel olmakla kalmamış aynı zamanda gelir idaresinin modern ülkelerle uyum içinde olabilmesine de imkan vermemiştir. Yapılanmadaki bu çift başlılığın sebep olduğu bir diğer olumsuzluk ise taşra yapılanmasının denetim açısından yeterince etkin olamaması nedeniyle objektif niteliğini kaybetmesidir. Bu çok başlılığın neden olduğu denetim elemanları içindeki koordinasyon eksikliği ve ihtiyaç 
duyulan düzenin kurulamaması sonucunda mükerrer vergi incelemesi durumları ortaya çıkmıştır (Gerçek, 2011: 32, Acar ve Aydın, 2011: 1; Savaşan vd. 2016: 38).

Şekil 2: Maliye Bakanlığı'nın VDK Öncesindeki Yapısı

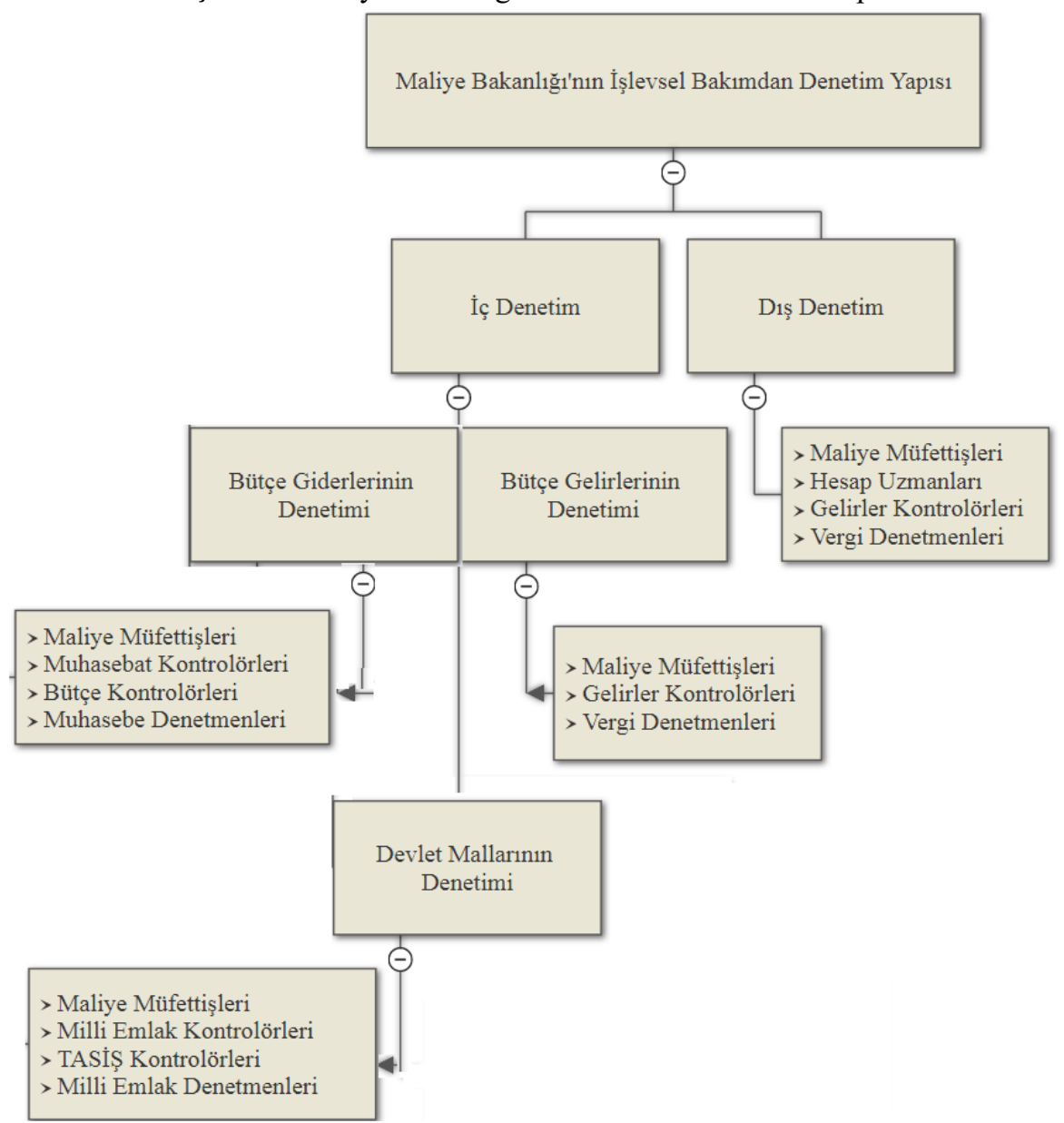

Kaynak: Gelen, Ş. (2015). Vergi Denetiminde Yapısal Dönüşüm: Vergi Denetim Kurulu. İstanbul: İstanbul Aydın Üniversitesi, s.19.

\section{B. Vergi Denetim Kurulu Başkanlığı Kuruluşu}

Yaşanan sorunların çözümü amacıyla geçmişten beri düşünülmüş olan vergi denetim birimlerini Maliye Bakanlığ çatısı altında tek ele indirmek fikri 10.07.2011 tarihinde 27990 sayılı Resmi Gazete'de yayımlanan 646 sayıl1 "Vergi Denetim Kurulu (VDK) Başkanlığının Kurulması Amacıyla Bazı Kanun ve Kanun Hükmünde Kararnamelerde Değişiklik Yapılmasına Dair Kanun Hükmünde Kararname"yle hayata geçirilmiştir.

Söz konusu KHK ile birlikte Maliye Teftiş Kurulu, Hesap Uzmanları Kurulu, Gelirler Kontrolörleri Başkanlığı ve Vergi Denetmenleri Büro Başkanlığ kurumlarına son verilerek, üstlenmiş oldukları görevler Vergi Denetim Kurulu'na devredilmiştir. Tablo 1 incelendiğinde 646 Sayılı KHK ile değişime uğrayan kadroları görmek mümkündür. 
Tablo 1: 646 Sayılı KHK ile Vergi Denetiminde Görevli Olanların Unvan Değişimleri

\begin{tabular}{|c|c|}
\hline ÖNCESİ & SONRASI \\
\hline Maliye Başmüfettişi & \multirow{3}{*}{ Vergi Başmüfettişi } \\
\hline Baş Hesap Uzmanı & \\
\hline Gelirler Baş Kontrolörü & \\
\hline Maliye Müfettişi & \multirow{4}{*}{ Vergi Müfettişi } \\
\hline Hesap Uzmanı & \\
\hline Gelirler Kontrolörü & \\
\hline Vergi Denetmeni & \\
\hline Maliye Müfettiş Yardımcısı & \multirow{4}{*}{ Vergi Müfettiş Yardımcısı } \\
\hline Hesap Uzman Yardımcısı & \\
\hline Stajyer Gelirler Kontrolörü & \\
\hline Vergi Denetmen Yardımcısı & \\
\hline
\end{tabular}

Tablo 1'den açıkça görüldügüü üzere 10.07.2011 tarihinde yayımlanan 646 sayılı KHK sonucunda Maliye Başmüfettişi, Baş Hesap Uzmanı ile Gelirler Başkontrolörü görevlerini yerine getirenler Vergi Başmüfettişi olarak; Maliye Müfettişi, Hesap Uzmanı ve Gelirler Kontrolörü ile Vergi Denetmeni statüsüne sahip denetim elemanları Vergi Müfettişi olarak; Maliye Müfettiş Yardımcısı, Hesap Uzman Yardımcısı ve Stajyer Gelirler Kontrolörü ile Vergi Denetmen Yardımcısı görevini ifa edenler Vergi Müfettiş Yardımcısı olarak görevlendirilmiştir.

\section{Vergi Denetim Kurulu Başkanlığı Mevcut Durum}

Başkan, Başkan Yardımcısı, Grup Başkanı ve Vergi Müfettişi (Vergi Başmüfettişi, Vergi Müfettişi ve Vergi Müfettiş Yardımcısı) üyelerinden oluşan Vergi Denetim Kurulu'nun merkezi Ankara'da bulunmaktadır.

VDK Başkanlığı öncelikli olarak, risk odaklı bir şekilde vergi denetimlerini gerçekleştirmek, kayıt altına alınmamış olan ekonomik faaliyetler ve yolsuzluklar ile etkin bir mücadele uygulamak, vergi idaresinin verimli ve hukuksal açıdan tam uyum içinde çalışmasını sağlayacak denetim ve soruşturma süreçlerini yürütmek amaciyla kurulmuştur. Söz konusu düzenlemeler ile birlikte vergi denetim süreci sonunda elde edilmek istenen hedefleri maddeler halinde belirtmek gerekirse (Ceylan, Tunal1 2011: 28; VDK F.R 2018: 5):

i. Mevcut durumda sorun teşkil eden vergi denetiminde çok başlilığ bunun oluşturduğu dağınıklığı ortadan kaldırmak,

ii. İhtiyaç duyulan uzmanlaşmayı sağlamak amacıyla gerekli görülen alt gruplandırmaları yaparak vergi incelemelerini gerçekleştirmek,

iii. Gerçekleştirilen vergi denetimlerinde etkinliği arttırmak,

iv. Vergi denetiminin bazı denetim birimlerinde yerleşmiş olan mesleki bağnazlık düşüncesine son vererek sadece performans nezdinde bir düzen ortaya çıkarmak,

v. Kayıt altına alınamamış alanlar üzerinde caydırıcı etki yaparak kayıt altına almayı başarmak, 
vi. Vergi incelemelerini gerçekleştirenlerin keyfi olarak gerçekleştirdiği uygulamalardan arındırılarak, kanunda belirtilen sisteme tam uyumunun sağlanması ve performans odaklı bir şekilde mesleklerinde kademe atlamalarına imkân verilerek çalışma ortamını verimli hale getirmek,

vii. Vergi denetiminin başarılı gençler arasından seçilen elemanlar ile gerçekleştirilerek uzun vadede etkin ve verimli çalışma ortamı neticesinde vergi denetim elemanlarının kalitesini arttırmak, şeklinde ifade etmek mümkündür.

VDK'nın öncelikli olarak üstlenmiş olduğu görev, risk odaklı olarak ve modern denetim yöntemleri kullanarak vergi denetimlerini gerçekleştirerek, vergi kayıplarının ve kaçaklarının sebep olduğu kayıt altına alınamamış ekonomiyi kayıt altına alarak küçültmek ve bu şekilde vergi mükelleflerinin vergi ödeme noktasında gönüllü uyumlarını azami noktaya çekmek, vergi idaresinin etkin ve hukuksal açıdan uygun bir şekilde işleyişini sağlama hedefiyle teftiş ve soruşturma süreçlerini yürütmek ve maliye politikasının hazırlanması hususunda gerekli hukuksal düzenlemelerin gerçekleşmesinde faydalı olmaktır (Oğuztürk ve Ünal 2015: 226).

VDK Başkanlığı aracılığıyla yürütülen vergi incelemelerinde, incelemeye alınan mükellefler belirlenirken esas alınan faktör sektöre, konuya ve mükellefe göre VDK Risk Analiz Merkezi'nde (VDK-RAMER) ve Vergi Denetim Kurulu Risk Analiz Sistemi'nin (VDK-RAS) oluşturduğu analizler ve mukayeselerdir.

VDK teftişlerindeki temel amaç; teftişi gerçekleştirilen birimi, hem mali işleri hem de organizasyon yapısını ve maddi imkânları bakımından gerektiği yerde, gereken amaca ve hukuki açıdan uygun olup olmadığı, risk analizleri özelinde değerlendirmelere tabi tutularak, sorunların çözümünde etkin yönetim ve iletişimlerin gerçekleştirilebilmesi noktasında idareye yardım ederek katk1 sağlamaktır (VDK Faaliyet Raporu, 2018: 20). Söz konusu amaçların gerçekleştirilmesi hususunda e-teftiş uygulamaları ile çalışmalar gerçekleştirilmektedir. E-teftiş uygulaması, geçmişten beri yürütülmüş olan teftiş yöntemlerinin elektronik ortamda gerçekleştirilmesi esasına dayanmaktadır.

VDK yapmış olduğu E-teftiş incelemelerini, "Denetim Bilgi Sistemleri (DEBISS)" şeklinde ifade edilen "Vergi Daireleri Denetim Bilgi Sistemi (VEDEBIS)", "Saymanlıklar Denetim Bilgi Sistemi (SADEBISS)" ile "Milli Emlak Denetim Bilgi Sistemi (MIDEBİS)" uygulamaları aracılığıyla yürütmektedir.

Vergi Denetim Kurulu Başkanlığı, 178 sayılı Maliye Bakanlığı'nın Teşkilat ve Görevleri Hakkında KHK'nın, 27990 sayılı ve 10.07.2011 tarihli Resmi Gazete'de yayımlanmış olan 646 sayılı KHK ile değişik, 19 ve 20'inci maddelerinde belirtilmiştir. 
Şekil 3: Maliye Bakanlığı bünyesinde Vergi Denetim Kurulu Başkanlığının Konumu

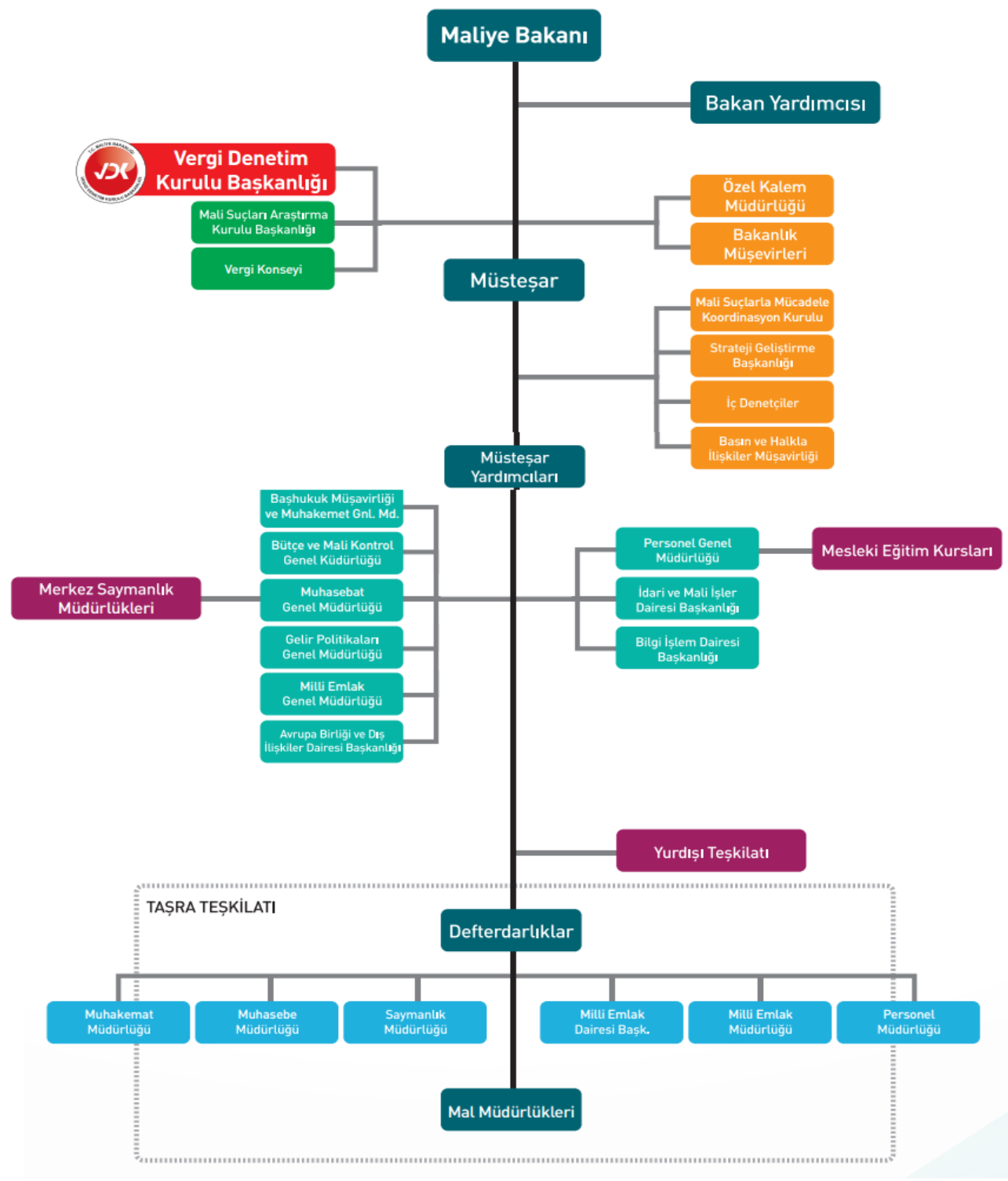

Kaynak: VDK 2018 Faaliyet Raporu

Şekil 3'den de açıkça görüldüğü üzere Maliye Bakanlığı'nın merkez teşkilatı çatısı altında yer alan VDK, "Danışma ve Denetim Birimi" olarak doğrudan Hazine ve Maliye Bakanı'na bağlı bir biçimde faaliyetlerini gerçekleştirmektedir (VDK. F.R, 2018).

Kurul, yürüttüğü faaliyetleri merkezde Başkan ve Başkana bağlı olmak üzere 5 Başkan Yardımcısı ile bir Şube Müdürlüğü (Özel Büro Müdürlüğü), 5 
Başkan Yardımcısına bağlı bulunan 20 Şube Müdürlüğü ile Ankara Eğitim Merkezi Küçük ve Orta Ölçekli Grup Başkanlığı'na bağl1 2 Şube Müdürlüğü aracılı̆̆gyla faaliyetlerini gerçekleştirmektedir. Öte yandan, şekil 3 'te de görüldüğü üzere VDK'da gerek görülen uzmanlaşma ve iş bölümünün sağlanarak iş gücünde verimliliğin arttırılması amacıyla Bakanın onayı ile direkt olarak Başkanlık çatısı altında Grup Başkanlıkları kurulmuştur.

\section{Ç. Vergi Denetim Kurulu Başkanlığının Yaşadığı Başlıca Sorunlar ve Çözüm Önerileri}

Ülkemizde vergi denetimine uyma noktasında tam olarak etkinlik ve verimlilik yakalanamamış olmasının birçok nedeni vardır. Bu nedenlerden birkaçı başlık olarak ele alınıp, bazı sorun ve öneriler sonuç kısmında birer cümle ile özetlenecektir. Burada başlık olarak verilecek sorunları şu şekilde sıralamak mümkündür:

i. Vergi denetiminde kalifiye eleman sayısındaki yetersizlik,

ii. Gerekli uzmanlaşmaların sağlanamamış olması,

iii. Mevzuatımızda yer alan uzlaşma müessesi ve sık sık başvurulan vergi afları, iv. Mükelleflerde vergi bilinci kavramının tam olarak özümsen(e)memiş olmasıdır.

\section{Vergi Denetim Elemanı Sayısının Yetersizliği ve Vergi Mükellefinin} Denetlenme Oranının Düşüklüğü

Kanunlar bir ülkenin sosyal ve ekonomik düzenine uygun olarak hazırlanmış ve gelir idaresi etkin işliyor olsa dahi, ihtiyaç duyulan etkin ve nitelikli bir vergi denetimi gerçekleştirilemiyorsa sistemin zamanla bozularak işlevselliğini kaybetmesi söz konusu olabilmektedir (Organ, 2008: 15).

VDK'da kadro imkânları 2018 yılı itibariyle \%54'lük bir doluluk oranına sahiptir $^{13}$ ve geçmiş yıllara göre azalan bu oran ${ }^{14}$ etkin ve verimli bir denetim sisteminin oluşturulabilmesi için gerek görülen denetim elemanı ihtiyacını karşılayamamaktadır.

Denetim ihtiyacının karşılanabilmesi adına VDK'da mevcut olan boş kadroların kalifiye denetim elemanları ile doldurularak denetim elemanlarının sayısının arttırılması, etkin vergi denetimi açısından büyük önem arz etmektedir.

Tablo 2. Y1llar İtibariyle Vergi İnceleme Oranı

\begin{tabular}{|c|c|c|c|c|}
\hline Yıllar & $\begin{array}{c}\text { Mükellef } \\
\text { Sayısı }\end{array}$ & $\begin{array}{c}\text { Incelenen } \\
\text { Mükellef Sayısı }\end{array}$ & $\begin{array}{c}\text { Inceleme } \\
\text { Oranı }\end{array}$ & $\begin{array}{c}\text { VDK Kadro Doluluk } \\
\text { Oranları }\end{array}$ \\
\hline $\mathbf{2 0 1 4}$ & 2.472 .658 & 55.284 & $2,24 \%$ & $64 \%$ \\
\hline $\mathbf{2 0 1 5}$ & 2.527 .084 & 58.676 & $2,32 \%$ & $64 \%$ \\
\hline $\mathbf{2 0 1 6}$ & 2.541 .016 & 49.817 & $1,96 \%$ & $59 \%$ \\
\hline $\mathbf{2 0 1 7}$ & 2.636 .370 & 44.182 & $1,68 \%$ & $57 \%$ \\
\hline $\mathbf{2 0 1 8}$ & 2.727 .208 & 44.376 & $1,63 \%$ & $54 \%$ \\
\hline
\end{tabular}

Kaynak: VDK F.R 2014/2015/2016/2017/2018

${ }^{13}$ Çalışmanın hazırlandığı tarihte (15.10.2020) VDK'nın 2019 Faaliyet Raporu henüz açıklanmamıştır.
${ }^{14}$ Bknz Tablo 2. 
VDK'daki kadro doluluk oranları ile doğrusal korelasyon içerisinde olan vergi denetim oranlarının düşüş eğilimi tablo 2'de açıkça görülmektedir.

\section{Yapılan Vergi İncelemelerinde Uzmanlaşma Eksikliği}

VDK bünyesinde görevli vergi denetim elemanlarının sayıca yetersiz olması nedeniyle, her tür vergi incelemesini yapması, her tür vergi konularının ve sektör bazlı çalışmalara dâhil olması sonucunu doğurarak, araştırma noktasında kullanılabilecek zamanın oldukça uzamasına sebep olmaktadır. Araştırmaya ayrılan zamanın uzaması neticesinde daha çok vergi mükellefinin incelemeye tabi olma ihtimali azalmakta, daha çok vergi kayıp ve kaçakçılığına sebep olmaktadır. Kurumda teorik anlamda bir ihtisaslaşma olsa da çalışma koşulları bu doğrultuda belirlenmemektedir (Kutbay, 2015:112).

\section{Uzlaşma Müessesesinin Varlığı ve Vergi Davalarında Vergi İdaresinin Gerektiği Ölçüde Kendi Haklarını Savunamaması}

Uzlaşma müessesine VUK'ta ilk kez 19.02.1963 tarihinde 205 sayılı kanunda yer verilmiştir. GİB uzlaşmayı vergi mükelleflerinin şahıslarına düzenlenen tarhiyatı kabul etmeyerek yargı yoluna taşımadan önce, vergi idaresi ile tahakkuk etmesi gereken vergilerin ve cezaların belirlenmesi noktasında anlaşabilecekleri idari çözüm yolu olarak tanımlamıştır (GIBB, 2007: 8)

Mükelleflerin rahat bir şekilde hareket etmesine neden olan uzlaşma müessesi sebebiyle vergi mükellefleri; vergi ve cezaya karşı muhatap olduktan sonra, uzlaşma seçeneğinin sunduğu imkanlarla, indirimler elde edebileceklerini düşünerek hareket edebilmektedirler. Bunun sonucunda denetimde etkinlikten uzaklaşılmaktadır.

\section{Vergi Afları}

Çıkarılan vergi aflarında amaç, kamunun sahip olduğu alacakların en kısa sürede tahsilini gerçekleştirmek, borç artıklarını ortadan kaldırarak tıpkı sıfır esaslı bütçeleme sistemi şeklinde mükellef ile ilişkilerde yepyeni bir sayfa açmaktır. Sıklıkla başvurulan vergi affı yöntemi, vergi cezalarının mükellef üzerindeki caydırıcılık etkisini yitirmesine, vergi ödeme konusunda ihtiyaç duyulan bilincin oluşamamasına, kayıt altına alınamamış ekonominin daha da büyümesine sebep olabilmektedir.

Vergi afları ile kısa vadede elde edilmesi beklenen gelire kıyasla uzun vadede mükellefin vergiye uyumu ve vergi adaletine bakış açısının zedelenmesi ile bunlar neticesinde ortaya çıkan vergi gelirlerindeki düşüşün yanı sıra toplum vicdanında yasal düzenlemelere karşı oluşan uyumun azalması ile fazlasıyla kayba neden olacaktır. Vergi aflarının kısa vadede ettirdiği fayda, uzun vadede sebep olacağı maliyetlerden çok daha az olmaktadır (Lerman, 1986:325-332).

S1klıkla başvurulan vergi aflarına karşı toplum üzerinde bir beklenti oluşturarak ekonomi üzerinde uzun vadede çok ciddi bozulmalara neden olabilmektedir. Cumhuriyetin ilanından günümüze kadar ortalama 3 yılda bir başvurulan vergi aflarına yönelik gerçekleştirilen düzenlemeler, vergi ödevini zamanında yerine getirmeyen vergi mükellefleri üzerinde bu davranışın alışkanlığa dönüşmesi sonucunu doğurmaktadır. Bunlara ek olarak söz konusu vergi afları, vergi denetimlerini gerçekleştiren vergi denetim elemanlarının vergi araştırma, 
saptama ve tahsilini sağlamak için harcadıkları emeklerin boşa gitmesine sebep olmaktadır (Kutbay, 2015:113-114). Bu nedenle vergi görevinin yerine getirilmesine olumsuz etki eden vergi afları, kısa vadedeki günlük kazançları yerine uzun vadede ortaya çıkan kayıpları göz önüne alınarak sıklıkla başvurulan bir yöntem olmaktan çıkarılmalı; vergi aflarının, vergi mevzuatının mütemmim cüzi olarak anılmasının önüne geçilmelidir.

\section{Mükelleflerde Vergi Bilinci Kavramının Tam Olarak Özümsen(e)memiş Olması}

Ülkede gerçekleştirilen vergi denetim sisteminde ihtiyaç duyulan etkinliğin sağlanabilmesi açısından vergi mükelleflerinin vergilendirmeye dair kurullara uygun hareket etmesi ve vergi mükellefiyetine ilişkin ödevlerini yerine getirmesi oldukça önem arz etmektedir (Gökbunar ve Gökbunar, 1996: 17).

Mükelleflerin vergiye uyumunu belirleyen unsurlar vergi algısı ile vergi bilincidir. Söz konusu unsurların mükellef üzerinde zayıf olması durumunda, vergi denetiminin zorluğu artarak vergi denetiminde etkinsizliğe neden olmaktadır. Bu sebeple, denetimde etkinlik sağlanmak isteniyorsa, olmazsa olmaz unsur vergi bilincinin mükellefler üzerinde oluşturulabilmesi gerekmektedir.

İhtiyaç duyulan vergi bilincinin oluşturulması konusunda en önemli husus, vergi mükelleflerinin ödemiş oldukları vergilerin kamu idaresi tarafindan ne şekilde kullanıldığının anlaşılır olmasıdır. Mükellefin eğer ödediği vergilerin tasarruflu kullanılmadığını düşünmesi halinde, vergi bilincinin geliştirilmesi süreci olumsuz etkilenebilmektedir. Yapılan kamu harcamalarının hesap verilebilir ve şeffaf olması, vergi idaresi ile mükellef ilişkilerinin güçlenmesi bakımından önemlidir. Görsel, işitsel medya araçların kullanımı da mükelleflerin vergi bilinç düzeylerinde artış sağlayarak, gönüllü uyum konusunda istenen seviyeye ulaşmasına katk1 sunacaktır (Kahriman, 2015:184; Uğur, 2016:6; Kutbay, 2015:113).

\section{SONUÇ}

Geçmişten günümüze vergi denetimi görevini üstlenen birçok kurum olmuştur. Osmanlı Devleti zamanından 2011 yılında çıkartılan 646 Sayılı KHK'ya kadar bu kurumları belirtmek gerekirse; Başbaki Kulları, Maliye Müfettişleri, Hesap Uzmanları, Gelirler Kontrolörleri, Vergi Denetmenleri bu hususta görev almış olan başlıca müesseselerdir.

Vergi kanunları çağın gereksinimlerini karşılayacak biçimde hazırlanmış olsa bile, getirmiş olduğu sistemin uygulanmasını sağlayacak yönetim yapısının doğru bir örgütlenme gerçekleştirmediği sürece uygulamadan istenilen sonuçların alınması mümkün olmamaktadır.

10.07.2011 tarihinde Resmi Gazete'de yayımlanarak yürürlüğe giren 646 Sayılı Kanun Hükmünde Kararname ile kamu denetiminde mevcut olan çok başlılık giderilerek tek bir çatı altında Maliye Bakanlığı'na doğrudan bağlı olarak ve uzmanlaşmaya dayalı olan Vergi Denetim Kurulu Başkanlığı kurulmuştur. Vergi Denetim Kurulu Başkanlığı'nın kuruluşu ile birlikte Maliye Bakanlığı çatısı altında örgütlenmiş olan Maliye Teftiş Kurulu, Hesap Uzmanları Kurulu'nun yanı sıra Gelir İdaresi Başkanlığı çatısı altında yer alan Gelirler Kontrolörleri Başkanlığı ve 
Vergi Denetmenleri sonlandırılarak Vergi Denetim Kurulu (VDK) bünyesinde "Vergi Müfettişi adı altında birleştirilmiştir. Ülke genelinde gerçekleştirilen vergi denetimlerinin tek bir elden yürütülmesi, etkinliğinin sağlanması, denetimlerde uyum içinde hareket edilmesi, insan gücünden etkinlik ve verimlilik bağlamında ideal seviyenin yakalanması açısından oldukça önemlidir.

Son olarak çalışma içinde belirtilen VDK'nın yaşadığı mevcut sorun ve çözüm önerilerine aşağıda yer alan maddeleride ekleyerek dikkat edilmesi gereken hususlar noktasinda tavsiyelerde bulunmak mümkündür:

i. Vergi denetimi esnasında vergi denetim elemanlarınca vergi mevzuatı tarafsız, öznel yargıdan uzak ve dış etkenlerin etkisi altında kalmadan uygulanmalidır

ii. Yalnızca hazine çıkarları göz önünde bulundurulmayarak mükellefin hukuki haklarına saygı gösterilmeli; yani vergi denetim elemanları bir avukat gibi değil mali bir savcı gibi görevlerini yerine getirmelidir.

iii. Vergi denetimi elemanları, kurum kültürüne bağlı, etik değerlere saygılı ve kendi içinde aktif olan bir otokontrol sistemi kurmuş olmalıdır.

iv. Vergi sisteminin karmaşıklaştırılmasının önlenmesi için, basitleştirme çabalarına hız verilmeli ve vergi denetimleri, mümkün olan en iyi ölçüde şeffaflaştırılmalı ve hesap verebilir duruma getirilmelidir.

v. Vergi denetimleri sonucunda kesilmiş olan cezaların yargı mercilerine taşınması durumunda, çok kısa sürede kesilen cezalar silinmektedir. Buna sebep olan ve sık sık başvurulan vergi afları sebebiyle mükellefler üzerinde oluşan "affinda affı çıkar" fikrinin yanlış olduğunu kabul ettirebilmek adına sistemde yer alan eksik yönler tespit edilerek çözüm odaklı çalışmalara ağırlık verilmelidir.

vi. Kurumda yer alan boş kadrolar nitelikli elemanlar ile kısa süre de doldurularak, ihtiyaç duyulan vergi denetim seviyesine ulaşmak adına mevcut kadro sayısında artışa gidilmelidir.

vii. Vergilendirmede istenilen başarının yakalanılmasının olmazsa olmazı olan vergi ödeme bilinci mükellefler üzerinde oluşturulmalıdır. Bu bilincin oluşturulabilmesi için ise vatandaşların ödedikleri vergilerin haklı sebeplere dayandığına ikna edilmeleri gereklidir.

viii. Uzmanlaşma, etkinlik ve verimlilik sağlanırken vergi denetim elemanları arasındaki kuruma zarar verecek nitelikteki çekişmelerden ve çatışmalardan mutlak suretle kaçınılmalıdır.

ix. VDK bünyesi dışında yapılanmış olan Mali Suçları Araştırma Kurulu gibi kurumların sürekli gereksinim duyduğu personel ya da bilgi ihtiyac1 noktasında VDK bünyesinden geçici süreyle görevlendirmeler şeklinde ihtiyacın karşılanmaya çalışılması yerine söz konusu kurumların VDK bünyesine dâhil edilerek gerçekleştirilen vergi denetimlerinde verimlilik arttırılabilir ve çok sık karşılaşılan personel eksikliği ve bilgi ihtiyacı sorunu kalıcı olarak çözüme kavuşturulabilir.

x.Maliye Müfettişliği gibi denetim unvanlarından vergi müfettişliği unvanlarına geçiş sürecinde, denetim elemanlarının sahip oldukları 
unvanların marka değerinin kaybolmuş olma hissini doğuran bir durum oluşmuştur. $\mathrm{Bu}$ nedenle, oluşan hissin ve bu his sonucunda oluşan motivasyon kayıplarının yok edilmesi, kurumun verimlilik düzeyinin arttırılmasında oldukça önemlidir. Kurum bünyesine dâhil edilmiş olan vergi denetim elemanlarının, bu noktada özlük haklarının azami seviyede korunması gerekmektedir.

\section{Araştırma ve Yayın Etiği Beyanı}

Makalenin tüm süreçlerinde Yönetim ve Ekonomi Dergisi'nin araştırma ve yayın etiği ilkelerine uygun olarak hareket edilmiştir.

\section{Yazarların Makaleye Katkı Oranları}

Makalenin tamamı Arş.Gör. Abdullah Marufoğlu ve Prof.Dr. Ramazan Gökbunar tarafindan kaleme alınmıştır. Yazarlar çalışmaya eşit oranda katkı sağlamıştır

\section{Çıkar Beyanı}

Bu çalışmada herhangi bir potansiyel çıkar çatışması bulunmamaktadır.

\section{KAYNAKÇA}

Akbıyık, S. (2005). Vergi Uygulamaları Yönüyle: Denetim ve Raporlama. Bursa: Ekin Kitapevi.

Akdoğan, A. (1979). Vergi İncelemesi (Doktora Tezi). Ankara: AİTİA Yayınc1lı.

Altınok, T. (2008). Maliye Teftiş Kurulu Ve Kamu Mali Denetim. Maliye Finans Yazılar1:<www.mmd.org.tr/wpcontent/uploads/eserler/Tevfik\%20ALTINOK.doc>

(17.02.2019).

Altuğ, O. (1994). Kayıtdışı Ekonomi. İstanbul: Cem Ofset Yayıncılık.

Arıca , N., \& İyibil, A. (1985). İsletmelerde Vergi Denetimi Defter ve Belgeler. Ankara: Fon Matbaası. Arif, B. (2016). "Yoklama İşlemleri ve Yoklamanın Vergi Kayıp ve Kaçağını Önlemedeki Rolü". EYaklaşım Dergisi, S.279.

Arslan, M. (2016). "Vergi Hukukunda Yoklamanın Etkinliği ve Elektronik Yoklama". Yaklaşım Dergisi, S.279.

Aslan, A. (1997). "Vergi Denetimi ve Vergi Denetiminde Etkinlik Sorunu”. Vergi Dünyası Dergisi, S.185.

Atılgan, H. (2004). Verginin Ekonomik Büyüme Üzerindeki Etkileri: Türkiye'deki Durumunun Analizi. Ankara: Hazine ve Maliye Bakanlığı.

Avcı, Ö. (2016). “71 Y1lın Ardından!”. Vergi Dünyası, S.418.

Aydın, M. B. (2006). Türkiye’de Kaylt dışı Ekonomide Vergi Denetiminin Önemi 2002-2007. İstanbul: Vergi Denetmenleri Derneği Yayını.

Aygün, R. (2012). "Vergi Afları ve Vergi Uyumuna Etkisi". Vergi Dünyast, S.369.

Baykara, B. (2007). "Vergi İncelemesi”. Vergi Dünyası, S.313.

Bölükbaşı, Ö. F. (2005). Tezyid-i Varidat ve Tenkih-i Masarifat: II. Abdülhamit Döneminde Mali İdare. İstanbul: Osmanlı Bankası Arşiv ve Araştırma Merkezi.

Can, İ. (1981). "Türkiye'de Vergi Denetimi Uygulaması ve Eleştirisi”. Maliye Dergisi, S.53.

Ceylan, M. A., \& Tunalı, A. (2011). "646 Say11 KHK Sonras1 Bir Değerlendirme: "Vergi Denetim Kurulu” Kuruluş Amacina Ne Kadar Hizmet Edebilecek?”. Vergi Dünyası, S.360.

Çelebiler, E., \& Güvemli , O. (2013). Tanzimat Dönemi Çağdaşlaşma Çabaları ve Maliye Teftiş Kurulunun Kuruluşu, Türk Muhasebe ve Denetim Düşüncesinin Son 150 Yll 1850-201. İstanbul: İstanbul Yeminli Mali Müşavirler Odası.

Çetin Gerger, G. (2007). "Vergi Aflarının Vergi Mükelleflerinin Tutum ve Davranışları Üzerindeki Etkisi”. Yönetim ve Ekonomi, S.2.

Demirci, A., \& Kartal, Z. (1999). "Vergi İncelemesi ve Kapsamı". Vergi Dünyast, S.211.

Doğan, A. (2015). Türkiye'de Kayıt Dışı Ekonominin Azaltılmasında Vergi Denetiminin Yapısl, Önemi ve Gelişimi. İstanbul Aydın Üniversitesi Sosyal Bilimler Enstitüsü.

Elgin , C., \& Özturnal1, O. (2012). Shadow Economies Around The World: Model Basedestimates. 〈http://www.econ.boun.edu.tr/public_html/RePEc/pdf/201205.pdf〉 
(29.02.2019).

Elgin, C. (2011). Vergiler ve Kayıt dışı Ekonomi: Bir Değerlendirme ve Türkiye Örneği. $\langle$ http://www.econ.boun.edu.tr/content/wp/EC2011_05.pdf> (08.02.2019).

Emecan, F. (1992). Başbâkî Kulu. İslam Ansiklopedisi (s. 125-127). İstanbul: Türkiye Diyanet Vakfi.

Erdağ , N. (2015). Risk Analizinden Vergi Denetimine Dikkat. <http://muhasebedr.com/riskanalizinden-vergi-denetimine-dikkat> (28.02.2019).

Erkuş, H., \& Karagöz, K. (2009). "Türkiye'de Kayıt dışı Ekonomi ve Vergi Kaybının Tahmini”. Maliye Dergisi, S.156.

Erol, A. (2010). Vergi Incelemesi \& Mükellef Hakları. İstanbul: İSMMMO.

Erol, A. (2011). 650 Yıllık Onur: Maliye Teftiş Kurulu. Vergi Felsefesi (Devlet ve Vergi) içinde (9199). İstanbul: İSMMMO.

Gelen, Ş. (2015). Vergi Denetiminde Yapısal Dönüşüm: Vergi Denetim Kurulu. İstanbul: İstanbul Aydın Üniversitesi Sosyal Bilimler Enstitüsü Yüksek Lisans Tezi.

Gökbunar, R., vd. (2002). Çağdaş Bir Vergi Ortamı Oluşturmak Iç̧in, Türkiye'de Vergi Idaresi Ve Vergi Denetimi Nasıl Yapılandırılmalıdır?. Ankara: Maliye Hesap Uzmanları Vakfi.

Gökbunar, R., \& Gökbunar, A. R. (1996). "Türk Vergi İdaresinin Verimliliğinin Artırılmasına Yönelik Reform Önerileri”. Verimlilik Dergisi, S.3.

Güney, A., \& Çekici, M. (2013). "XX. Yüzyılın Oralarında Türkiye'de Öncü Bir Kamu Vergi Denetçisi ve Öncü Bir Muhasebe Düşünürü: Rasim Saydar (1901-1966)”. Muhasebe ve Finans Tarihi Araştırmaları Dergisi, S.40.

HUD, 2020, http://www.hud.org.tr/tarihimiz, Erişim Tarihi:19.04.2020

Kahriman, H. (2016). "Vergiye Gönüllü Uyum Çerçevesinde Türkiye'de Gelir İdaresinin Organizasyon Yapısı Üzerine Bir Değerlendirme". Ekonomik ve Sosyal Araştırmalar Dergisi, S.12.

Karatepe, S. (2019) \& Çapar, S. "Türkiye Cumhuriyeti Bakanlıklar Tarihi”, s. 504. TİAV, 2019, Ankara.

Kutbay, H. (2015). “Almanya Ve Abd'deki Vergi Denetimi İle Türkiye'de Vergi Denetimindeki Aksaklıklar". Vergi Dünyası, S.403.

Lerman, A. H. (1986). Tax Amnesty: The Federal Perspective. National Tax Journal.

Macunluoğlu, Ö. U. (2010). Kamu Mali Yönetiminin Yeniden Yapılandırılmasında Gelir Denetiminin Değerlendirilmesi. Bursa: Uludağ Üniversitesi, Sosyal Bilimler Enstitüsü Yüksek Lisans Tezi.

Oğuztürk, B. S., \& Ünal, E. K. (2015). “Türkiye'de Vergi Denetiminde Yeni Dönem”. Akademik Araştırmalar ve Çalışmalar Dergisi, S.13.

Organ, İ. (2008). Vergi Denetimi ve Türkiye Uygulamast. Ankara: Gazi Kitapevi.

Öner, E. (2005). Osmanlı Imparatorluğu ve Cumhuriyet Döneminde Mali İdare. Ankara: Uyum Yayıncilik.

Pekşen, F. (2019). Osmanlı Devletinden Günümüze Vergi Denetiminin Tarihçesi. ODÜ Sosyal Bilimler Araştırmaları Dergisi (ODÜSOBİAD), 9(1), 107-116.

Perviz Pur, H. (2015). Osmanlı'da Vergi İsyanları. İstanbul: Tarihçi Kitapevi Yayınları.

Rakıcı, C. (2011). "Vergi Denetiminin Yeni Yapısı ve Denetimin Kayıt dışılığı Önleme Fonksiyonu". ZKÜ Sosyal Bilimler Dergisi, S.14.

Sarıl1, M. A. (2004). Türkiye'de Gelir İdaresi ile Vergi Denetiminin Sorunları, Çözüm Önerileri ve Yeniden Yapılandırllması. İstanbul: İTO Yayınc1lı.

Savaşan, F., Şahpaz İzgi, K., \& İnce, T. (2016). "Vergi Denetim Birimlerindeki Değişikliğin Vergi Müfettişleri Gözüyle Değerlendirilmesi: Bir Alan Araştırmasi”. 29. Türkiye Maliye Sempozyumu Tebliğler Kitabı. Beşiz Yayıncılık.

Schneider, F., Raczkowski, K., \& Mróz, B. (2015). "Shadow Economy and Tax Evasion in the EU". Journal of Money Laundering Control, S.18.

Somuncu , A. (2014). "Yaygın ve Yoğun Vergi Denetimi: Hukuki Yapı ve Uygulamanın Değerlendirilmesi". Erciyes Üniversitesi İktisadi ve İdari Bilimler Fakültesi Dergisi, S.43.

Tabakoğlu, A. \& Taşdirek, O. Ç. (2015). “Osmanlıda Mali Denetimin Kurumsal Gelişimi - Maliye Teftiş Heyetinin Kuruluşu”. Yönetim ve Ekonomi Araştırmaları Dergisi, S.2. 
Abdullah Marufoğlu \& Ramazan Gökbunar / Başbaki Kulluğu'ndan Vergi Denetim Kurulu Başkanlığı'na Vergi Denetim Müesseseleri, Günümüz Sorunlarl ve Çözüm Önerileri

Tezcan, K. (2003). "Türk Vergi İdairesinin Tarihsel Gelişimi ve Bu Süreçte Geçirdiği Aşamaların Etkinlik Açısından Değerlendirilmesi”. Çukurova Sosyal Bilimler Enstitüsü Dergisi, S.12.

Uğur, A. A. (2016). "Vergi Denetimi Etkinliğinde, Risk Analizi Sisteminin Uygulanabilirliği (Gaziantep Halı Sektörü Üzerine Örnek Bir Uygulama)". 2016 Maliye Sempozyumu. Mersin.

Varcan Nezih. (2000). Osmanlı Maliyesi Hakkında Ingiliz Raporlarl (1861-1892). Ankara: Hazine ve Maliye Bakanlığı.

Vergi Denetim Kurulu Faaliyet Raporu. (2012-2013-2014-2015-2016-2017-2018).

Yaraşl1, G. O. (2005). Türkiye'de Vergi Reformu. Ankara: Hazine ve Maliye Bakanlığı.

Ek 1: Başbaki Kulu'nun Tuttuğu Muhasebe Kaydının Bir Örneğini Gösteren Vesika

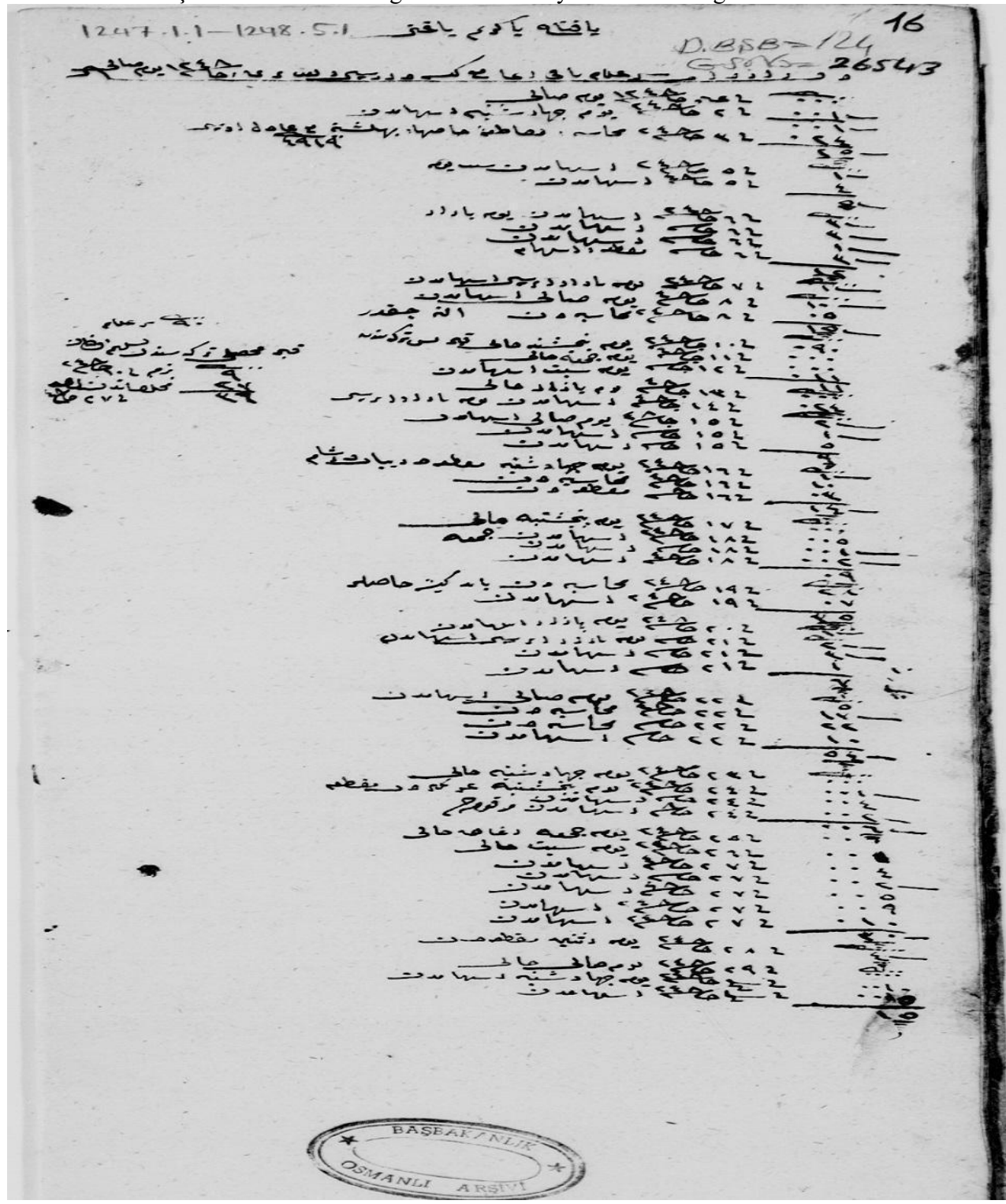

Kaynak: Yazarlar tarafından T.C. Cumhurbaşkanlı̆̆ı Devlet Arşivleri Başkanlığı'ndan çıkartılmıştır. 
Ek 2: Niğde ve Fizan Vilayetlerinde Çalışmakta Olan Maliye Müfettişlerinin Terfileri Hakkında Vesika.

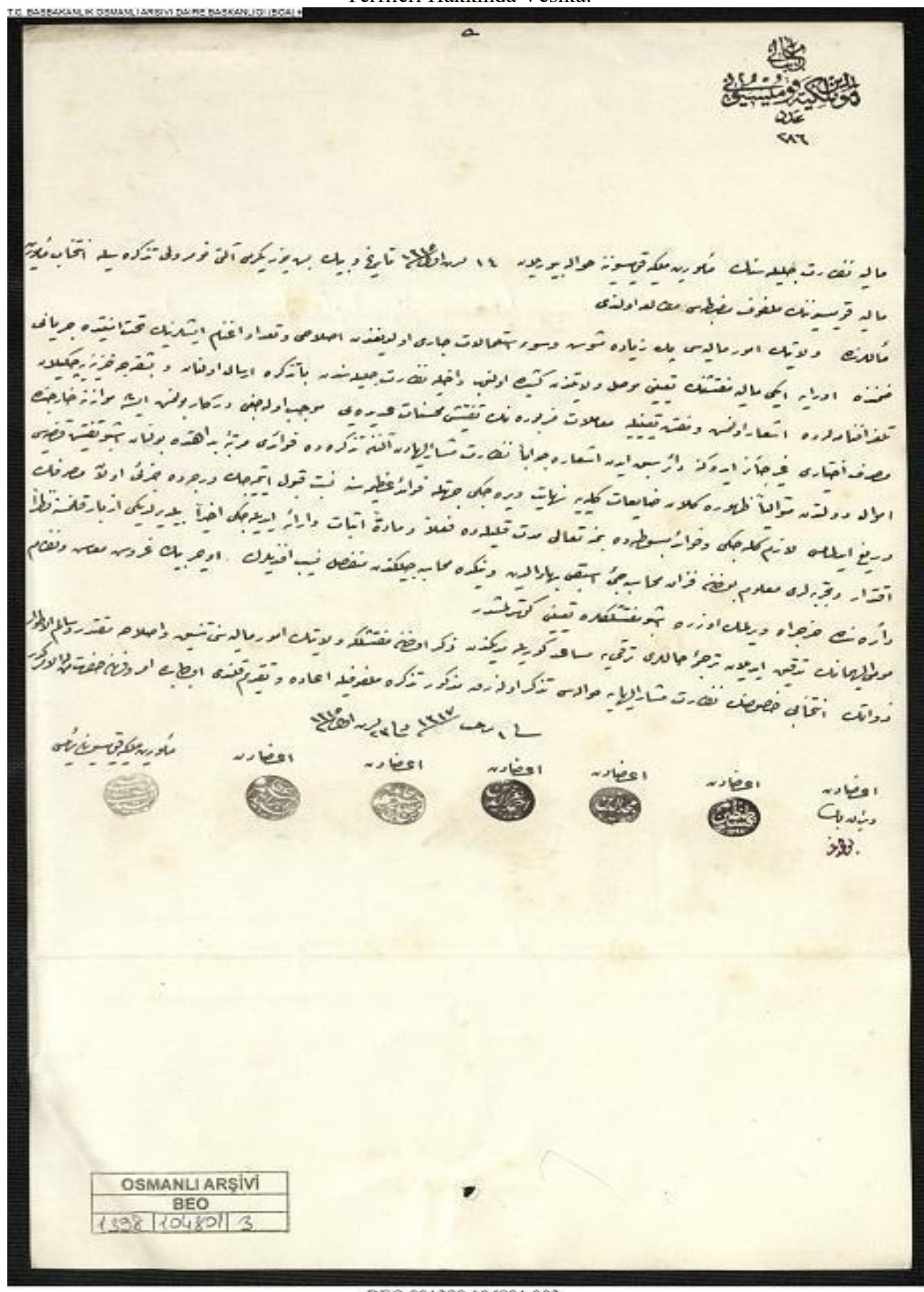

BE0.001398,104801.003

Kaynak: Yazarlar tarafından T.C. Cumhurbaşkanlığı Devlet Arşivleri Başkanlığı'ndan çıkartılmıştır. 


\section{SUMMARY}

Tax auditing process is the ultimate regulatory function of the state to prevent tax evasion. This authority should be used in a timely and efficient manner. In this regard, it is an indispensable necessity to act objectively within the boundaries of modern law while disregarding the traditional values and subjective judgments.

Inspectors or institutions exercising their supervisory power on behalf of the state authority should take modern law as their guide. Legal system should be refined of the legal holes, nepotism and inconsistencies among the laws. In this context, the units with tax audit authority and the employees working in these units should be selected very carefully. It is imperative to provide the necessary conditions while the employees are performing their duties.

Taxes are in the most critical position for states to finance public expenditures. Therefore, it is evident that the problems in the tax collection will result in economic, social and especially financial problems. The problems in tax collection should be carefully examined to eliminate these problems. Therefore, the registration and taxation of the unregistered economy should be a priority. Preventing tax losses caused by those who operate informally is only possible by eliminating the factors that cause unregistered work.

Various legal regulations have been made to reduce unregistered activities. A fundamental reform was realized with the Decree-Law No. 646 (Decree-Law), which entered into force after being published in the Official Gazette on 10.07.2011. With Decree No. 646, the state employment inconsistencies existing under public inspection were eliminated. The Tax Inspection Board, which is directly affiliated with the Ministry of Finance and based on specialization, has been established. With the establishment of the Tax Inspection Board, the Finance Inspection Board organized under the Ministry of Finance, the Tax Inspectors Board as well as the Revenue Controllers Presidency under the Revenue Administration, the Tax Inspectors were terminated, and the tax inspector within the Tax Inspection Board has been united under a single title. In this way, the Tax Inspection Board Presidency was established as a vital institution within the Ministry of Finance. With the reform realized, the foundation of an order under a single institution based on specialization was laid. Although the foundation has been laid, it will inevitably take time for this foundation to grow. When the activity reports of the Tax Inspection Board from 2011 to 2016 are examined, a significant improvement in the quality of tax audits is not demonstrated. However, as the institution develops, these rates are sure to improve over time. 